\title{
Leucine-rich diet alters the eukaryotic translation initiation factors expression in skeletal muscle of tumour-bearing rats Gislaine Ventrucci ${ }^{1}$, Maria Alice R Mello ${ }^{2}$ and Maria Cristina C Gomes- Marcondes*1
}

Address: ${ }^{1}$ Laboratório de Nutrição e Câncer, Departamento de Fisiologia e Biofísica, Instituto de Biologia, Universidade Estadual de Campinas (UNICAMP), Campinas, 13083-970, São Paulo, Brazil and ²Departamento de Fisiologia e Biofísica, Instituto Biociências, Universidade Estadual de São Paulo, UNESP, Rio Claro, 13506-900, São Paulo, Brazil

Email: Gislaine Ventrucci - ventrucci@hotmail.com; Maria Alice R Mello - mellomar@rc.unesp.br; Maria Cristina C GomesMarcondes* - cintgoma@unicamp.br

* Corresponding author

Published: 6 March 2007

BMC Cancer 2007, 7:42 doi:10.1/86/147|-2407-7-42
Received: 26 November 2006

Accepted: 6 March 2007

This article is available from: http://www.biomedcentral.com/I47/-2407/7/42

(c) 2007 Ventrucci et al; licensee BioMed Central Ltd.

This is an Open Access article distributed under the terms of the Creative Commons Attribution License (http://creativecommons.org/licenses/by/2.0), which permits unrestricted use, distribution, and reproduction in any medium, provided the original work is properly cited.

\begin{abstract}
Background: Cancer-cachexia induces a variety of metabolic disorders on protein turnorver, decreasing protein synthesis and increasing protein degradation. Controversly, insulin, other hormones, and branched-chain amino acids, especially leucine, stimulate protein synthesis and modulate the activity of translation initiation factors involved in protein synthesis. Since the tumour effects are more pronounced when associated with pregnancy, ehancing muscle-wasting proteolysis, in this study, the influence of a leucine-rich diet on the protein synthesis caused by cancer were investigated.
\end{abstract}

Methods: Pregnant rats with or without Walker 256 tumour were distributed into six groups. During 20 days of experiment, three groups were fed with a control diet: $\mathrm{C}$ - pregnant control, $\mathrm{W}$ - tumour-bearing, and $\mathrm{P}$ - pair-fed, which received the same amount of food as ingested by the $\mathrm{W}$ group; three other groups of pregnant rats were fed a leucine-rich diet: $L$ - pregnant leucine, WL - tumour-bearing, and PL - pair-fed, which received the same amount of food as ingested by the WL group.

Results: The gastrocnemius muscle of WL rats showed increased incorporation of leucine in protein compared to $\mathrm{W}$ rats; the leucine-rich diet also prevented the decrease in plasma insulin normally seen in $\mathrm{W}$. The expression of translation initiation factors increased when tumour-bearing rats fed leucine-rich diet, with increase of $\sim 35 \%$ for elF $2 \alpha$ and elF5, $~ 17 \%$ for elF4E and $20 \%$ for elF4G; the expression of protein kinase $\mathrm{S} 6 \mathrm{KI}$ and protein kinase $\mathrm{C}$ was also highly enhanced.

Conclusion: The results suggest that a leucine-rich diet increased the protein synthesis in skeletal muscle in tumour-bearing rats possibly through the activation of elF factors and/or the S6kinase pathway.

\section{Background}

Cancer-cachexia induces a variety of metabolic disorders, including marked weight loss, especially in adipose and muscle tissues [1]. Skeletal muscle loss causes alterations 
in protein metabolism that involve a decrease in protein synthesis and an increase in protein degradation $[2,3]$. Insulin, other hormones, and nutrients such as branchedchain amino acids [4], stimulate protein synthesis.

Leucine, a branched-chain amino acid, stimulates muscle protein synthesis and modules the activity of various proteins involved in the control of mRNA translation $[5,6]$. Leucine can stimulate protein synthesis directly and/or via its metabolite, $\alpha$-ketoisocaproic acid (KIC) [7]. Protein synthesis is regulated by interactions between mRNA, tRNA and eukaryotic initiation factors (eIFs). Leucine can stimulate translation via the mammalian target of rapamycin (mTOR) or independently [8-10]. In addition, leucine can stimulate glucose uptake by protein kinase $\mathrm{C}$ (PKC), in contrast to insulin which modulates glucose uptake via protein kinase B (PKB) [11].

During the early stages of rat pregnancy, protein is synthesized and accumulated in the maternal organism and is later mobilized during the last days of pregnancy to provide substrates for the fetus [12]. To some extent, the fetus can be compared to rapid tumor growth since both tissues have an exponential growth and are dependent on an adequate supply of glucose and amino acids [13]. For this reason, the association between cancer and pregnancy may change the nutritional supply to both tumour and fetal tissues. Our previous results showed that the total body protein wasting can be enhanced in this situation $[13,14]$ and prevented by nutritional supplementation with leucine [14]. Knowing this, the aim of this study was to examine the effects of a leucine-rich diet on the increased protein degradation and reduced protein synthesis seen in the skeletal muscle of tumour-bearing pregnant rats.

\section{Methods}

\section{Animals and diets}

Young female Wistar rats (45 days old, $\mathrm{n}=60$ ) were obtained from the animal facilities of the State University of Campinas (UNICAMP). The rats were housed overnight with adult males ( 4 females: 1 males), using the harem method [15]. The first day of pregnancy was determined based on the detection of sperm in the vaginal smear. All pregnant rats were then housed in collective cages with free access to water and food under standard conditions $\left(22 \pm 2{ }^{\circ} \mathrm{C}, 12 / 12\right.$-h light/dark cycle). During 20 days, the animals were fed with the semipurified diets which consisted of a balanced control diet (C, 18\% protein, AIN-G93) and a leucine-rich diet (L, 15\% protein with $3 \%$ leucine), both containing the same amount of carbohydrate $(63 \%)$, fat $(7 \%)$ and fibres $(5 \%)$, in accordance with the AIN-G93 recommendations [16]. Corn Products Brazil Ingredients supplied some of the diet components, (corn standard and dextrin), whereas the vitamin mix was from DSM Nutritional Products Brazil
Ltda., and the amino acids were from Ajinomoto Interamericana Ind. \& Com. Ltda., Brazil. The pregnant rats were randomly distributed into six groups. Three groups were fed the control diet: $\mathrm{C}$ - pregnant control, $\mathrm{W}$ - tumourbearing, and $\mathrm{P}$ - pair-fed, with the latter receiving the same amount of food as ingested by the $\mathrm{W}$ group; three other pregnant groups were fed the leucine-rich diet: $\mathrm{L}-$ pregnant leucine, WL - tumour-bearing, and PL - pairfed, the latter receiving the same amount of food as ingested by the WL group.

\section{Tumour implantation}

The rats assigned to the tumour-bearing groups, $\mathrm{W}$ and $\mathrm{WL}$, received a subcutaneous injection of Walker 256 tumour cells (approx. $0.25 \times 10^{6}$ viable cells in $0.5 \mathrm{~mL}$ of saline solution) in the right flank after the confirmation of pregnancy. As a standard procedure, the pregnant groups without tumours $(\mathrm{C}, \mathrm{L}, \mathrm{P}$ and $\mathrm{PL}$ ) received a single injection of $0.5 \mathrm{~mL}$ of $0.9 \% \mathrm{NaCl}(\mathrm{w} / \mathrm{v})$ in the right flank. All groups were monitored for 20 days after tumour implantation. The general UKCCCR [17] guidelines for animal welfare were followed, and the protocols were approved by the institutional Committee for Ethics in Animal Research (CEEA/IB/UNICAMP, protocol 217-5).

\section{Experimental procedures}

The rats were killed 20 days after tumor implantation and the gastrocnemius muscles were collected to analyse the incorporation of leucine into muscle protein, and to assess the expression of eukaryotic initiation factors, S6K1 and PKC. Plasma samples were collected to measure the insulin concentration by radioimmunoassay (RIA) [18]. Leucine incorporation was assayed in right gastrocnemius muscles, which were weighed and placed in Krebs-Henseleit bicarbonate (KHB) buffer (composition, in mM: $\mathrm{NaCl}$ $110, \mathrm{NaHCO}_{3} 25, \mathrm{KCl} 3.4, \mathrm{CaCl}_{2} 1, \mathrm{MgSO}_{4} 1, \mathrm{KH}_{2} \mathrm{PO}_{4} 1$, glucose 5.5, pH 7.4) supplemented with $1.26 \mathrm{mmol} / \mathrm{L}$ leucine. The muscles were pre-incubated separately for 30 min at $37^{\circ} \mathrm{C}$ with continuous aeration $\left(95 \% \mathrm{O}_{2}-5 \% \mathrm{CO}_{2}\right)$ and shaking, as described by Vary et al. [19]. After this period, new KHB buffer supplemented with [ $\left.{ }^{3} \mathrm{H}\right]$-leucine (10 $\mu \mathrm{Ci} . \mathrm{L}^{-1}$; Amersham Biosciences, Little Chalfont, Buckinghamshire, UK) was added and the incubation was continued for a further $2 \mathrm{~h}$. At the end of this period, the muscles were homogenised in trichloroacetic acid (TCA, $1: 3 \mathrm{w} / \mathrm{v})$, centrifuged at $10,000 \times \mathrm{g}$ for $15 \mathrm{~min}$ at $4^{\circ} \mathrm{C}$ and the pellet was suspended in $1 \mathrm{M} \mathrm{NaOH}$ and incubated at $40^{\circ} \mathrm{C}$ for $30 \mathrm{~min}$. Aliquots of this supernatant were used to measure the total protein [20] and to quantity the radioactivity by liquid scintillation using a $\beta$-counter. The rates of incorporation were calculated based on the amount of radioactive leucine incorporated in a $2 \mathrm{~h}$ period and expressed as pmols $\left[{ }^{3} \mathrm{H}\right]$-Leu per mg of muscle protein [19]. 


\section{Quantification of elF2, elF4E, elF4G, elF5, p70 S6KI and $P K C$ in gastrocnemius skeletal muscle}

Aliquots of muscle samples were weighed and homogenised in buffer $(20 \mathrm{mM} \mathrm{N}$-2-hydroxyethylpiperazine-N-2ethanesulfonic acid, $100 \mathrm{mM} \mathrm{KCl}, 0.2 \mathrm{mM}$ EDTA, $2 \mathrm{mM}$ EGTA, $1 \mathrm{mM}$ dithiothreitol, $50 \mathrm{mM} \mathrm{NaF}, 1 \mathrm{mM}$ 3,3'diaminobenzide tetrahydrochloride (DAB), $0.5 \mathrm{mM}$ orthovanadate, and $50 \mathrm{mM}$ glycine, $\mathrm{pH}$ 7.4) followed by centrifugation at $10,000 \times g$ for $15 \mathrm{~min}$ at $4^{\circ} \mathrm{C}$. Skeletal muscle proteins were resolved by SDS-PAGE on $12 \%$ gels followed by transfer of the proteins to a $0.45 \mu \mathrm{m}$ Hybond$\mathrm{C}$ nitrocellulose membrane (Amersham). All of the antibodies were purchased from Santa Cruz Technology (Santa Cruz, CA, USA). The level of eIF2 $\alpha$, eIF4E and eIF4G expression was assessed using a monoclonal rat antibody against eIF2 $\alpha$, eIF4E and eIF4G (diluted 1:750) followed by detection with a secondary anti-goat horseradish peroxidase (HRP)-labelled antibody (diluted 1:1000). The expression of eIF5 was assessed using an anti-rabbit monoclonal eIF5 (1:750) followed by detection with a secondary anti-rabbit antibody (1:1000). p70S6 kinase expression was assessed using a specific antimouse monoclonal S6K1 (1:1000) followed by detection with a secondary anti-mouse antibody (1:1000). Protein kinase $\mathrm{C}$ was detected with an anti-mouse antibody against PKC (1:1000) and a secondary monoclonal antimouse antibody HRP. Actin (Boehringer Mannheim, Germany) was used as the loading control and was probed with a mouse anti-actin antibody. All of the blots were developed using enhanced chemiluminescence (ECL) reagent (Amersham) and the immunoreactive bands were quantified by densitometry. Images of the gels were captured (FTI 500 Image Master VDS, Pharmacia Biotech) and densitometric analyses of the bands were done using Gel Pro Analyser software (Media Cybernetics, Silver Spring, MD, USA).

\section{Statistical analysis}

The results were expressed as the mean \pm SEM. The statistical comparisons were done using one-way ANOVA [21] followed by Bonferroni's test for comparisons among groups. All statistical calculations were done using GraphPad Prism software, v3.00 (GraphPad Inc., San Diego, CA, USA). A value of $\mathrm{P}<0.05$ indicated significance.

\section{Results}

The incorporation of leucine into gastrocnemius muscle protein is shown in Figure 1. Tumour growth reduced leucine incorporation in the tumour-bearing groups, $\mathrm{W}$ and $\mathrm{WL}$, compared to the respective control groups, $\mathrm{C}$ and $\mathrm{L}$. However, the leucine incorporation in the tumour-bearing group fed the leucine-rich diet (WL) was not significantly different from that of the $\mathrm{L}$ group. The incorporation of leucine into muscle protein was 23\% lower in the tumour-bearing group $(\mathrm{W}=12.00 \pm 2.17$ pmol $\left.\left[{ }^{3} \mathrm{H}\right]-\mathrm{Leu} / \mathrm{mg} / \mathrm{h}\right)$ compared to the WL group (15.61 $\left.\pm 1.21 \mathrm{pmol}\left[{ }^{3} \mathrm{H}\right]-\mathrm{Leu} / \mathrm{mg} / \mathrm{h}\right)$. The pair-fed groups, $\mathrm{P}$ and $\mathrm{PL}$, showed no significant difference compared to the $\mathrm{C}$ and L groups (Figure 1). Recent studies have shown that skeletal muscle protein synthesis is stimulated by branched-chain amino acids, especially leucine, administered orally or in perfused muscle [22-24].

Leucine and other branched-chain amino acids stimulate insulin synthesis and release in rats [25]. Tumour growth markedly decreased the plasma insulin concentration in the group $\mathrm{W}$ compared to groups $\mathrm{C}$ and $\mathrm{P}(\mathrm{C}=6.013 \pm$ 1.000 ng.mL $L^{-1} ; \mathrm{W}=0.785 \pm 0.077$ ng. $\mathrm{mL}^{-1}{ }^{*} ; \mathrm{P}=3.500 \pm$ 0.408 ng. $\mathrm{mL}^{-1}{ }^{*} \mathrm{p}<0.05$ compared to $\mathrm{C}$ and $\left.\mathrm{P}\right)$.This finding agreed with other studies in Walker tumour-bearing rats that reported a reduction in the plasma insulin level caused by a decrease in insulin synthesis and release by the $\beta$-cells of pancreatic islets $[26,27]$. The leucine-rich diet prevented the decrease in plasma insulin level associated with tumour growth in the WL group $(\mathrm{L}=6.216 \pm$ 0.872 ng. $\mathrm{mL}^{-1} ; \mathrm{WL}=3.547 \pm 0.286^{*} ; \mathrm{PL}=5.019 \pm 0.552$; ${ }^{*} \mathrm{p}<0.05$ compared to $\mathrm{C}$ and $\left.\mathrm{P}\right)$. In addition, the decrease in plasma insulin concentration in the WL group $(\sim 1.7-$ fold)was significantly less than in the $\mathrm{W}$ group ( 7.6fold).

Protein synthesis is a complex process that involves a number of protein factors and ribosomal structures. The initiation of protein synthesis requires eIF2 activity that induces the GTP-dependent binding of Met-tRNAi to the $40 \mathrm{~S}$ ribosomal subunit to form a preinitiation complex $[3,28]$. The expression of eIF2 $\alpha$ (Figure 2A) increased in the groups fed a leucine-rich diet. The increase in eIF2 $\alpha$ expression was $\sim 22 \%$ in the L group, but was not significantly different from the control group $\mathrm{C}$. In groups $\mathrm{WL}$ $(0.194 \pm 0.012$ arbitrary densitometric units) and PL $(0.195 \pm 0.007$ arbitrary densitometric units $)$, the elF $2 \alpha$ expression increased by $\sim 35 \%$ and $\sim 27 \%$ compared to groups $\mathrm{W}(0.126 \pm 0.012)$ and $\mathrm{P}(0.142 \pm 0.003)$, respectively. Factor eIF5 catalyses the binding of GTP to eIF2 factor in the preinitiation complex [29]. In our experiments, eIF5 expression was higher in WL than in W rats $(0.1685$ \pm 0.0052 vs. $0.1054 \pm 0.0056$ arbitrary densitometric units; $\mathrm{p}<0.001$ ) (Figure 2B).

The activity of the eIF4F complex, which involves the assembly of three initiation factors, including eIF4E and eIF4G, is necessary for recognition and binding of the $43 \mathrm{~S}$ complex to the $5^{\prime}$ terminal of mRNA and for optimal translation $[29,30]$. Expression of the subunit eIF4E, which recognises the 5 ' terminal $\mathrm{m} 7 \mathrm{GTP}$ cap structure at the 5' end of eukaryotic mRNA [30], was significantly reduced in $\mathrm{W}$ rats compared to the other groups, especially WL rats (Figure 3A; $\mathrm{C}=0.0516 \pm 0.0009, \mathrm{~W}=$ $0.0429 \pm 0.0014^{*}, \mathrm{P}=0.0468 \pm 0.0023, \mathrm{~L}=0.0485 \pm$ 


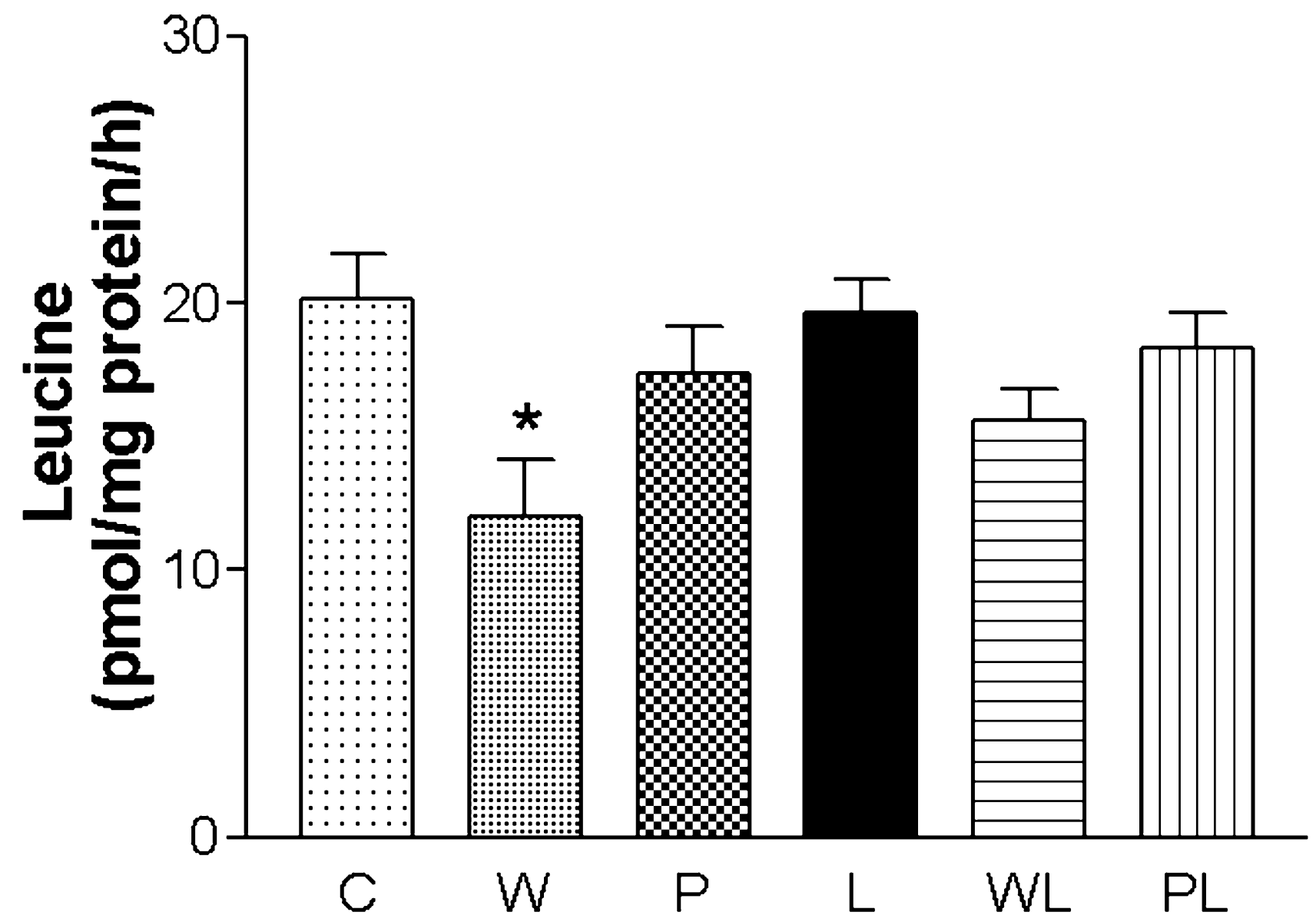

Figure I

Effects of a leucine-rich diet on leucine incorporation into protein in gastrocnemius skeletal muscle from pregnant, tumourbearing rats. Right gastrocnemius muscles from all experimental groups were incubated with [ $\left.{ }^{3} \mathrm{H}\right]$-L-Leucine for $2 \mathrm{~h}$. For details, see Methods. At least 10 rats were used per group. Abbreviations: C, control; W, tumour-bearing rats; P, pair-fed tumour-bearing rats; L, leucine-rich diet group; WL, tumour-bearing rats fed a leucine-rich diet; PL, pair-fed tumour-bearing group fed a leucine-rich diet. The columns are means \pm SEM. $* P<0.05$ estatistically different compared to all groups.

$0.0008, \mathrm{WL}=0.0519 \pm 0.0013$ and $\mathrm{PL}=0.0528 \pm 0.0014$ arbitrary densitometric units; ${ }^{*} \mathrm{p}<0.01$ compared to groups C, WL and PL). Similarly, eIF4G, the subunit that binds to the $43 \mathrm{~S}$ preinitiation complex, was less expressed in tumour-bearing rats $(\mathrm{W}=0.0987 \pm 0.0014$ arbitrary densitometric units) compared to the other groups $(\mathrm{C}=$ $0.1222 \pm 0.0093, \mathrm{P}=0.1040 \pm 0.0045, \mathrm{~L}=0.1329 \pm$ 0.0066 and $\mathrm{PL}=0.1101 \pm 0.0037$ arbitrary densitometric units), while the leucine-rich diet significantly increased eIF4G expression by $\sim 20 \%$ in the WL group compared to $\mathrm{W}(0.1253 \pm 0.0024$ vs. $0.0987 \pm 0.0014$ arbitrary densitometric units, $\mathrm{p}<0.05$ ) (Figure $3 \mathrm{~B}$ ).

The oral administration of leucine increases the phosphorylation of S6K1 in rat muscles [31]. There was a reduction in S6K1 expression in the gastrocnemius muscle of $\mathrm{W}$ rats compared to $C$ rats $(0.182 \pm 0.005$ vs. $0.473 \pm 0.007$ arbitrary densitometric units) (Figure $4 \mathrm{~A}$ (WB image) and $4 \mathrm{~B}$ ). Although the expression of S6K1 in WL rats was lower than in $L$ rats $(0.362 \pm 0.005$ vs. $0.470 \pm 0.005$ arbitrary densitometric units), the expression of this kinase was $\sim 32 \%$ higher in WL rat muscle than in W rats $(\mathrm{p}<0.001)$. PKC expression was significantly higher $(\mathrm{p}<0.001)$ in all groups fed the leucine-rich diet $(\mathrm{L}=0.156 \pm 0.018, \mathrm{WL}=$ $0.161 \pm 0.012, \mathrm{PL}=0.154 \pm 0.011$ arbitrary densitometric units) compared to those fed the control diet $(C=0.086$ $\pm 0.003, \mathrm{~W}=0.071 \pm 0.002$ and $\mathrm{P}=0.102 \pm 0.003$ arbitrary densitometric units). However, there was no significant difference between the WL and L (control) groups $(0.161 \pm 0.011$ vs. $0.156 \pm 0.018$ arbitrary densitometric units) (Figure 4A (WB image) and 4C), although this parameter was 2.27-fold higher in WL than in $\mathrm{W}$ rats. 

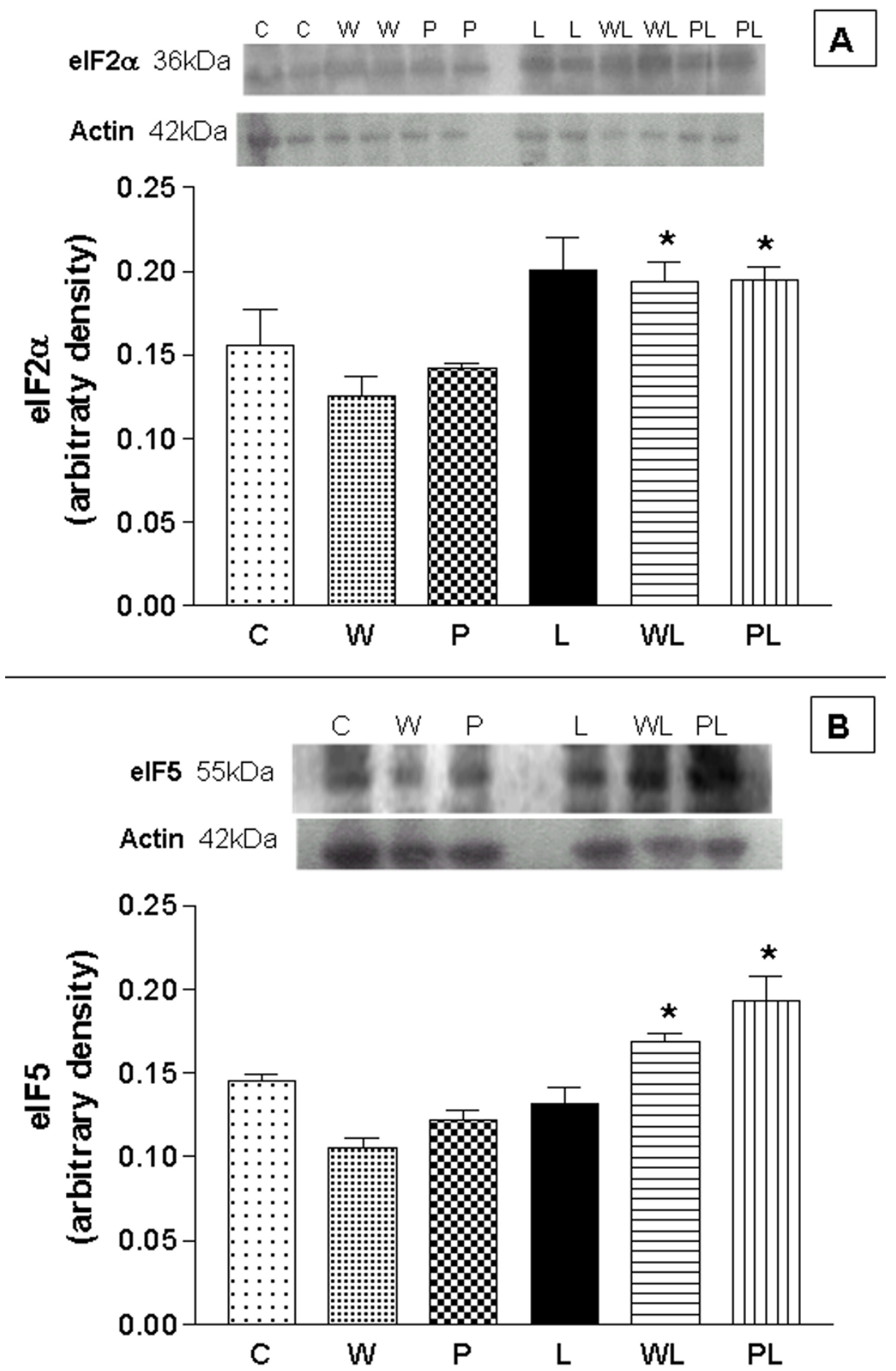

Figure 2

Effects of a leucine-rich diet on the expression of initiation factors in gastrocnemius skeletal muscle from pregnant, tumourbearing rats. Western blot images and arbitrary densitometric values for the expression of elF2 $\alpha$ (A) and elF5 (B). Aliquots of gastrocnemius muscle homogenates were loaded onto SDS-PAGE gels ( $5 \mathrm{\mu g}$ protein/well) and, after electrophoresis, the proteins were transferred to nylon membranes and blotted with antibodies to elF2 $\alpha$ and elF5 ( $I: 750$ dilution). For details, see Methods. Abbreviations are defined in the legend to Figure I. The columns are the means \pm S.E.M. of at least 10 rats per group. There was no variation in the expression of actin $(42 \mathrm{kDa})$. $* P<0.05$, for comparison WL vs W and PL vs $\mathrm{P}$. 

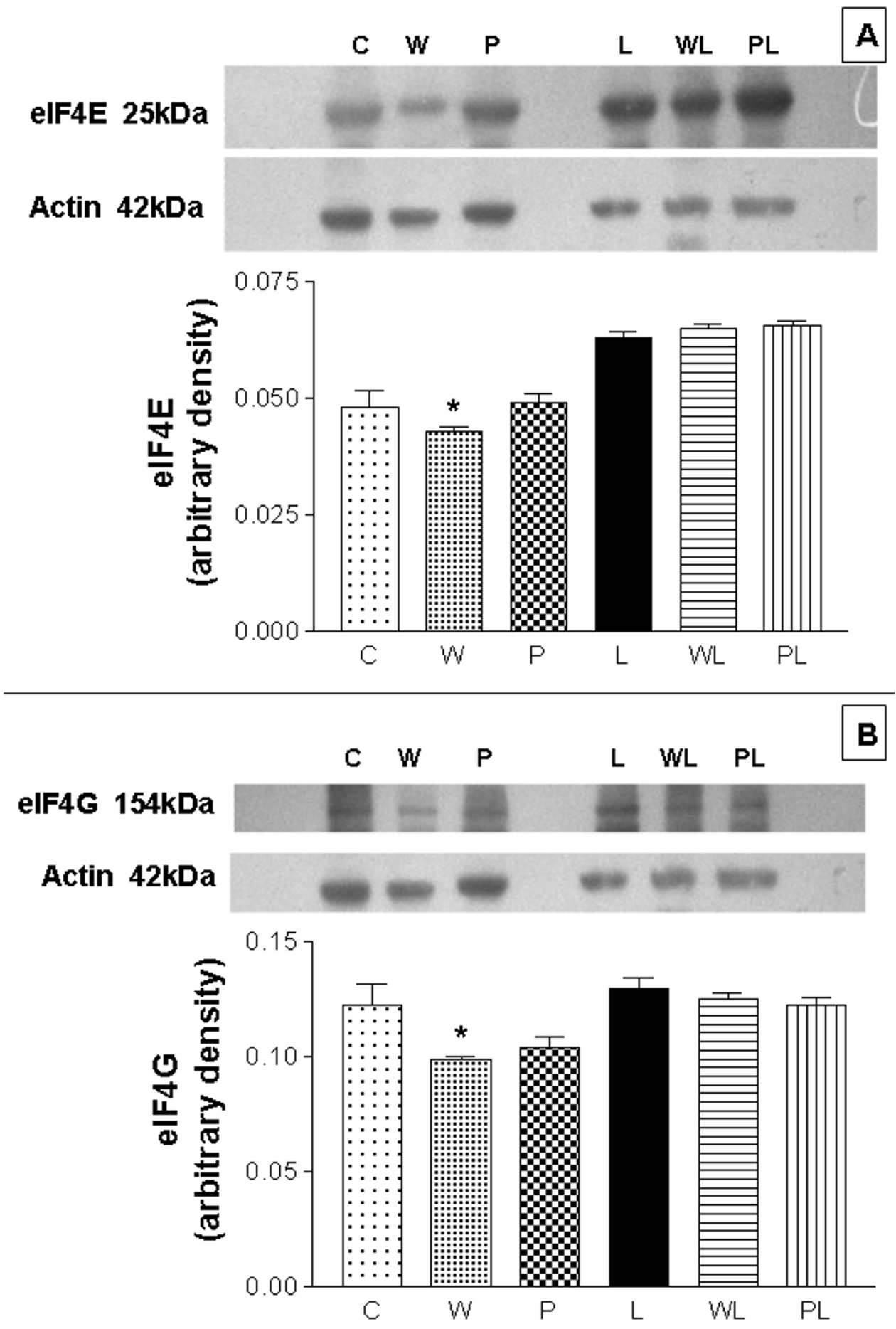

Figure 3

Effects of a leucine-rich diet on the expression of initiation factors in gastrocnemius skeletal muscle from pregnant, tumourbearing rats. Western blot images and arbitrary densitometric values for the expression of elF4E (A) and elF4G (B). Aliquots of gastrocnemius muscle homogenates were loaded onto SDS-PAGE gels ( $5 \mathrm{\mu g}$ protein/well) and, after electrophoresis, the proteins were transferred to nylon membranes and blotted with antibodies to elF4G and elF4E ( $\mathrm{I}: 750$ dilution). For details, see Methods. Abbreviations are defined in the legend to Figure I. The columns are the means \pm S.E.M. of at least 10 rats per group. There was no variation in the expression of actin $(42 \mathrm{kDa})$. $* P<0.05$ for comparison with all groups. 

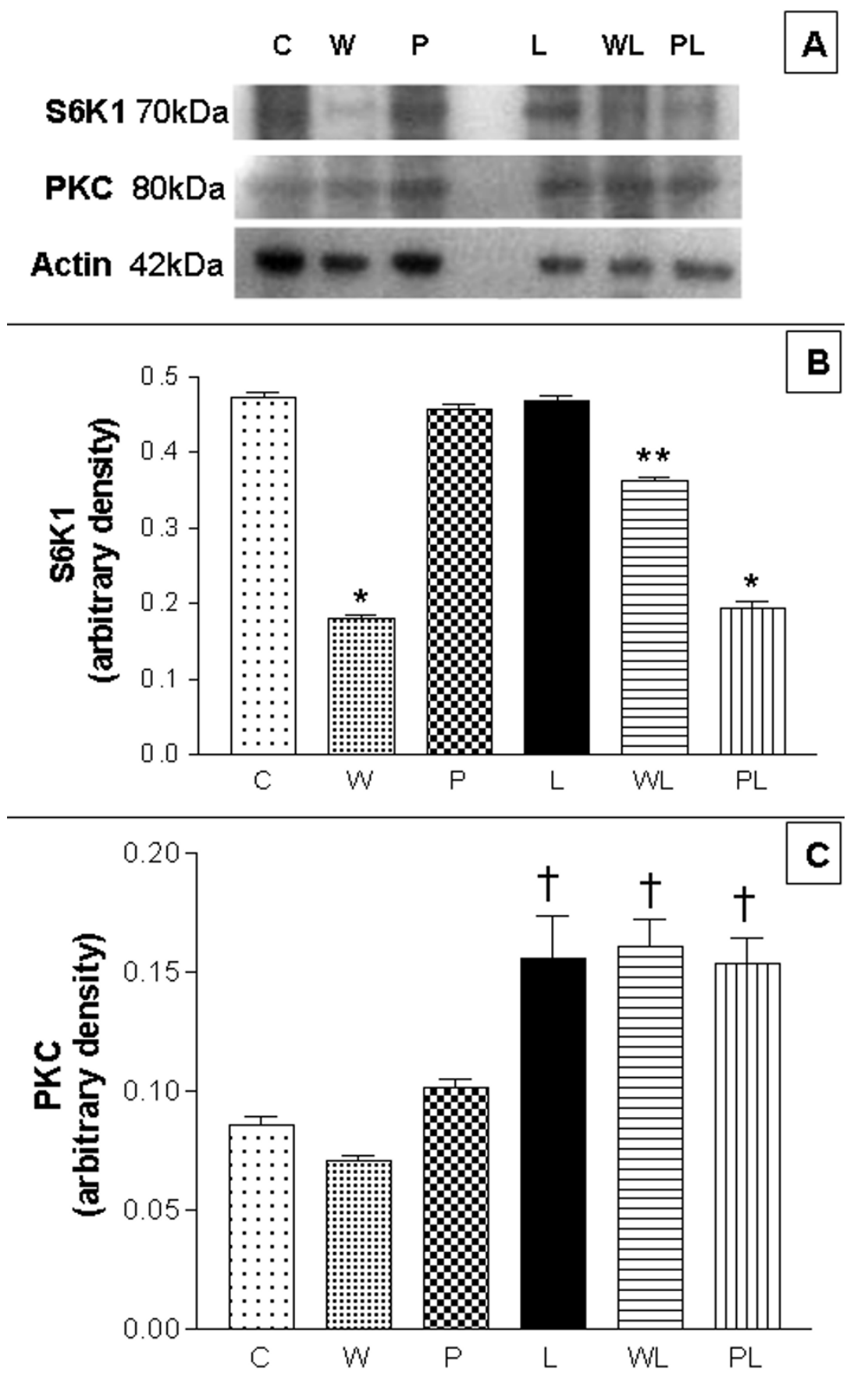

Figure 4

Effects of a leucine-rich diet on the expression of initiation factors in gastrocnemius skeletal muscle from pregnant, tumourbearing rats. (A) Western blot images of S6KI $(70 \mathrm{kDa}), \mathrm{PKC}(80 \mathrm{kDa})$ and actin $(42 \mathrm{kDa})$. These images are representative of the best assay from each group (minimum of 10 rats per group). (B) Arbitrary densitometric values for S6KI expression from western blots of eight rats per group. (C) Arbitrary densitometric values for PKC expression from western blots of eight rats per group. Aliquots of gastrocnemius muscle homogenates were loaded onto SDS-PAGE gels ( $5 \mu \mathrm{g}$ protein/well) and, after electrophoresis, the proteins were transferred to nylon membranes and blotted with antibodies to elF2 $\alpha$ and elF5 (I:I500 dilution). For details, see Methods. Abbreviations are defined in the legend to Figure I. The columns are the means \pm S.E.M. of at least 8 rats per group. There was no variation in the expression of actin $(42 \mathrm{kDa})$. $* \mathrm{P}<0.05$ for comparison W vs $\mathrm{C}$ and $\mathrm{WL}$, $\mathrm{PL}$ vs $\mathrm{P}$; ** $\mathrm{P}<0.05$ for comparison $\mathrm{WL}$ vs $\mathrm{L} ; \nmid \mathrm{P}<0.05$ for comparison $\mathrm{L}$ vs $\mathrm{C}, \mathrm{WL}$ vs $\mathrm{W}, \mathrm{PL}$ vs $\mathrm{P}$. 


\section{Discussion}

Cachexia, a severe condition in cancer patients, involves wasting of the body tissues with a loss of muscle mass that may reduce performance, the response to chemotherapy, and life expectancy. Since the depletion of lean body mass in cancer cachexia is the major factor in decreasing the survival time, an improvement in protein synthesis and/or a reduction in protein catabolism could interfere with physiological processes involved in patient welfare. As shown here, a leucine-rich diet improved the protein metabolism of muscle tissue by enhancing the expression of eukaryotic initiation factors that is normally depressed during tumour growth. Since protein synthesis is reduced and protein degradation is increased throughout the body during cancer cachexia, the incorporation of amino acids, especially branched-chain amino acids, by muscle cells could supply important nutrients and influence protein synthesis. The lower incorporation of leucine into gastrocnemius muscle proteins in tumour-bearing rats indicated a decrease in protein synthesis that paralleled an increase in protein wasting, as previously reported by ourselves $[1,2,32]$ and others $[33,34]$. As shown here, the leucinerich diet reduced the protein catabolism and increased the protein synthesis in WL rats compared to W rats.

The rate of protein synthesis depends on the nutritional and physiological status of the animal [35-37], including the availability of dietary protein and amino acids $[8,38]$, although in the pair-fed groups studied here (P and PL) there was no reduction in leucine incorporation into muscle protein compared to the tumour-bearing groups. In animals and human pregnancy [12-14,36,37] the protein synthesis is highly activated, especially during the early stages of pregnancy. The findings in pair-fed groups suggested that food restriction caused less wasting of muscle protein than did tumour growth. Even at the late stage of pregnancy in rat, there is protein synthesis associated to high proteolysis [12-14,36,37], providing substracts to fetus and also to tumor cells [14]. This fact suggests that the rapid tumor growth-induced hypercatabolism in pregnant rats shows more evident effects on protein turnover.

In recent years, the impact of nutrients on cell signalling events and the regulation of protein synthesis by branched-chain amino acids have become an important area of research [39]. Protein synthesis involves many eukaryotic initiation factors (eIFs) that are involved in a complex, multistage process regulated by three steps $[29,40]$. The first step involves association of the $40 \mathrm{~S}$ ribosomal subunit with eIF2 and GTP to form a ternary complex (eIF2-GTP-Met-tRNA), with eIF2 $\alpha$ being a key target in translational regulation [41]. The reduction in skeletal muscle protein synthesis seen during cancer cachexia (W group, previously observed in our study [2]) was associated with a decrease in eIF $2 \alpha$ and eIF5 expres- sion and a reduction in leucine incorporation, indicating the ability of tumour growth to produce important tissue wasting. On the other hand, eIF2 $\alpha$ expression was strongly enhanced in the leucine-treated groups (L, PL and especially LW) and was correlated with increased eIF5 expression and the maintenance of leucine incorporation. Since eIF5 is a catalytic factor for many translation factors, including the release of eIF2-GDP from met-tRNA, then once the eIF2-GDP complex is released it may participate in another round of initiation, with GDP being exchanged for GTP prior to the formation of a new eIF2-GTP-met-t RNA complex.

The second step in the initiation of translation involves the binding of mRNA to the 40S ribosomal subunit, an interaction that is mediated by a triad of initiation factors including eIF4E, which associates with eIF4G to form an active complex (eIF4F) $[29,35,39,40]$. The decreased eIF4E expression seen in tumour-bearing rats suggested that there was less translation and, consequently, less protein synthesis since eIF4E is necessary for assembly of the eIF4G-eIF4E complex which modulates the overall rate of protein synthesis. The enhanced formation of eIF4F may involve the phosphorylation of eIF4G, which is correlated with the stimulation of protein synthesis [42]. Similarly, decreased eIF4G-eIF4E assembly and a corresponding decrease in eIF4G phosphorylation in the presence of mTOR activation has been observed in the skeletal muscle of septic rats $[43,44]$.

The leucine-dependent stimulation of mRNA translation is partly insensitive to rapamycin [45]. This finding is supported by the observation that skeletal muscle protein synthesis and eIF4E-eIF4G assembly are enhanced by the administration of leucine in the presence of rapamycin (a specific inhibitor of mTOR) [45]. Additionally, oral leucine administration enhanced the phosphorylation of $4 \mathrm{E}$ BP1, showing the stimulation effect of leucine on protein synthesis in skeletal muscle of normal rats [46]. Conversely, leucine alone has beneficial effects on skeletal muscle metabolism in tumour-bearing animals [2]. As shown here, leucine tended to increase the expression of eIF4G in skeletal muscle. This slight increase in the amount of eIF4G could result in greater binding to eIF4E. The regulation of the initiation of translation depends on the availability of eIF4E [35], the levels of which were maintained in the leucine-rich diet group (LW). The oral administration of isoleucine, which is less effective than leucine, activates the initiation of translation in skeletal muscle in rats [23], and the binding of eIF4G to eIF4E is enhanced by isoleucine and leucine in rats [27,31,47]. Another mechanism for regulating protein synthesis is the phosphorylation of the ribosomal protein S6 that is mediated by the $70 \mathrm{kDa}$ ribosomal protein S6 kinase (S6K1) 
[48]. The activation of S6K1 increases the capacity to synthesise protein $[39,45]$.

The cellular mechanisms by which amino acids modulate protein synthesis are now beginning to be understood. Amino acids, and leucine in particular, consistently activate S6K1 and promote translation [49]. Among branched-chain amino acids, leucine apparently has the greatest effect in activating S6K1 [50,51]. Since increased S6K1 activity has been associated with increased protein synthesis and enhanced translation of mRNA [52], our results suggest that the leucine pathways in muscle protein synthesis require an increased availability of eIF4E, and S6K1 activity. The availability of leucine could activate $S 6 \mathrm{~K} 1$, as verified by Yoshizawa and collegues $[46,53]$ thereby enhancing the protein synthesis in gastrocnemius muscle, as seen in the WL, L and PL groups. Although Yoshizawa and collegues [46,53] observed increase on translational factos activity after 1 hour leucine feeding, the authors found that this stimule reduced to basal level after $3 \mathrm{~h}$. Controvertly, in the present study, probably the increased on eIF4E, and S6K1 were directely related to the constant stimule by the leucine-rich diet intake, during 20 days. This activation could be mediated by mTOR through different mechanisms [54].

Several reports have suggested a possible interplay between leucine, mitochondrial function and mTOR signalling [55,56]. Xu et al. [57] proposed that leucine stimulates S6K1 phosphorylation via the mTOR pathway, partly by serving as a mitochondrial fuel through oxidative carboxylation and partly by mediating the allosteric activation of glutamate dehydrogenase, thereby decreasing the activity of AMP-activated protein kinase (AMPK). Leucine enhances glucose uptake by the PKC-dependent pathway $[4,11]$, and the increased PKC expression in all of the groups fed a leucine-rich diet suggested that leucine improved the glucose uptake and minimised the effects of cancer-cachexia in skeletal muscle (WL).

When amino acids and glucose are present in adequate amounts, AMPK, which usually inhibits the mTOR-S6K1 pathway, is depressed and there is an increase in protein synthesis [55]. Although cancer-cachexia decreases plasma insulin levels [58,59], the leucine-rich diet improved the plasma insulin level in the LW group, and could serve as a stimulus for protein synthesis [60]. The oral administration of leucine in vivo results in transient increases in circulating insulin, but blocking this response with somatostatin prevents the leucine-induced hyperphosphorylation of 4E-BP1 and S6K1 in rat skeletal muscle, whereas formation of the eIF4E-eIF4G complex is increased [25,31]. However, amino acids do not stimulate phosphatidylinositol 3-kinase(PI3-K) or protein kinase B (PKB) (Akt) signalling pathways activated by insulin and growth factors [50,61,62]. Bolster and colleagues [63] reported that leucine had no effect on 4E-BP1 and S6K1 during skeletal muscle protein synthesis, in contrast to the findings of studies in vivo [23] and in vitro [64] which suggested that the residual insulin signalling seen in postabsorptive state rats provided the basal phosphorylation for 4E-BP1 and S6K1; however, this level of signalling was insufficient to cause hyperphosphorylation, regardless of the availability of leucine.

Although the combined effect of leucine and insulin provides an integrated response, leucine alone may preferentially enhance the expression and activity of selected components of translation initiation, thereby increasing protein synthesis. As shown here and elsewhere [2], a leucine-rich diet increased protein synthesis in skeletal muscle of tumour-bearing rats and thereby enhanced the levels of many signalling factors. The finding that leucine influenced the synthesis of eIF factors and/or activated the S6kinase pathways could lead to new alternatives for complimentary treatment during cancer therapy. Specifically, we are currently investigating whether leucine supplementation can counteract body weight loss during cancer cachexia by inducing protein synthesis.

\section{Conclusion}

The oral administration of leucine-rich diet induced the increase on the protein synthesis in skeletal muscle in tumour-bearing rats possibly through the activation of eIF factors and/or the S6kinase pathway.

\section{Competing interests}

The author(s) declare that they have no competing interests.

\section{Authors' contributions}

The author G.V. contributed to the data collection, analysis, data interpretation, and manuscript preparation. The author M.A.R.M. participated in the design of the study and contributed to manuscript preparation. The author M.C.C.G.M. conceived the study and its design and coordinated the works and manuscript preparation. All authors read and approved the final manuscript.

\section{Acknowledgements}

The authors thank Dr. Juvenal Marcondes Neto for computational assistance. This study was supported by grants from Fundação de Amparo à Pesquisa do Estado de São Paulo (FAPESP, 96/9463-6, 01/02 I35-3, 02/ 04464-7 and 04/005 I4-5), Conselho Nacional de Desenvolvimento Científico e Tecnológico (CNPq, 52 1048/95-8, 522755/96-8 and 350047/03-0), Coordenação de Aperfeiçoamento de Pessoal de Nível Superior (CAPES) and Fundo de Apoio ao Ensino e à Pesquisa (FAEP-UNICAMP).

\section{References}

I. Gomes-Marcondes MCC, Ventrucci G, Toledo MT, Cury L, Cooper JC: A leucine-supplemented diet improved protein content 
of skeletal muscle in young tumor-bearing rats. Braz J Med Biol Res 2003, 36:1589-1594.

2. Ventrucci G, Mello MAR, Gomes-Marcondes MCC: Proteasome activity is altered in skeletal muscle tissue of tumour-bearing rats fed a leucine-rich diet. ERC 2004, I I:887-895.

3. Vary TC, Kimball SR: Effect of sepsis on eIE4E availability in skeletal muscle. Am I Physiol Endocrinol Metab 2000, 279:EII78-EII84

4. Nishitani S, ljichi C, Takehana K, Fujitani S, Sonaka I: Pharmacological activities of branched-chain amino acids: specificity of tissue and signal transduction. Biochem Biophysical Res Com 2004, 313:387-389.

5. Kimball SR, Jefferson LS, Nguyen HV, Suryawan A, Bush JÁ, Davis TA: Feeding stimulates protein synthesis in muscle and liver of neonatal pigs through an mTOR-dependent process. $\mathrm{Am} J$ Physiol Endocrinol Metab 2000, 279:El 080-EI087.

6. Beugnet A, Tee AR, Taylor PM, Proud CG: Regulation of targets of mTOR (mammalian target of rapamycin) signalling by intracellular amino acid availability. Biochemical J 2003, 372:555-566.

7. Nissen S, Sharp R, Ray M, Rathmacher JA, Rice D, Fuller JC Jr, Connelly AS, Abumrad N: Effect of leucine metabolite betahydroxy-beta-methylbutyrate on muscle metabolism during resistance-exercise training. J Appl Physiol 1996, 8I (5):2095-104.

8. Fedele MJ, Thomas CV, Farrell PA: Selected contribution: IGF-I antibody prevents increases in protein synthesis in epitrochlearis muscles from reefed, diabetic rats. J App Physiol 200I, 90:1166-1173.

9. Holecek M, Sprongl L, Tilser I: Metabolism of branched-chain amino acids in starved rats: the role of hepatic tissue. Physiol Res 200I, 50:25-33.

10. Proud CG: Regulation of mammalian translation factors by nutrients. Euro J Biochem 2002, 269:5338-5349.

II. Nishitani S, Matsumura T, Fujitani S, Sonaka I, Miura Y, Yagasaki K: Leucine promotes glucose uptake in skeletal muscles of rats. Biochem Bioph Res Com 2002, 299:693-696.

12. Freinkel N, Metzger BE: Metabolic changes in pregnancy. In Williams Textbook of Endocrinology 8th edition. Edited by: Wilson JD, Foster DW. Saunders, Philadelphia; 1992:993-1006.

13. Gomes-Marcondes MCC, Cury L, Curi R: Consequences of Walker 256 tumor growth for the placental/fetal development in rats. Cancer Res Ther Contr 1998, 5:277-283.

14. Ventrucci G, Mello MA, Gomes-Marcondes MC: Effect of a leucinesupplemented diet on body composition changes in pregnant rats bearing Walker 256 tumor. Braz J Med Biol Res 200I, 34(3):333-8.

15. Baker HL: Reproduction and breeding. In The Laboratory Rat, ch. 7 Volume I. Edited by: Baker HL, Lindseyl JR, Weisbroth SH. New York: Academic Press; 1991:153-168.

16. Reeves PG, Nielsen FH, Fahey J: AIN-93 purified diets for laboratory rodents: final report of the American Institute of Nutrition ad hoc writing committee on the reformulation of the AIN-76 rodent diet. J Nutrition 1993, I 23:1939-195 I.

17. Vale C, Stewart L, Tierney J: Trends in UK cancer trials: results from the UK Coordinating Committee for Cancer Research National Register of Cancer Trials. $\mathrm{Br}$ J Cancer 2005 92(5):8I I-4.

18. Malaisse WJ, Malaisse-Lagae F, Wright PH: Effect of fasting upon insulin secretion in the rat. Am J Physiol 1967, 2 I 3:843-848.

19. Vary TC, Dardevet D, Grizard J, Voisin L, Buffiere C, Denis P, Breuille $D$, Obled C: Differential regulation of skeletal muscle protein synthesis turnover by insulin and IGF-I after bacteremia. Am J Physiol Endocrinol Metab 1998, 275:E584-E593.

20. Bradford MM: A rapid and sensitive method for quantification of microgram quantities of protein utilising the principle of protein-dye-binding. Anal Biochem 1976, 72:248-254.

21. Gad SC, Weil CS: Statistic for toxicologists. In In Principles and Methods of Toxicology Edited by: Wallace H. New York: Raven Press; 1994:221-274.

22. Anthony JC, Anthony TG, Layman DK: Leucine supplementation enhances skeletal muscle recovery in rats following exercise. I Nutrition 1999, 129: I 102-1106.

23. Anthony JC, Anthony TG, Kimball SR, Vary TC, Jefferson LS: Orally administered leucine stimulates protein synthesis in skeletal muscle of postabsorptive rats in association with increased elF4F formation. J Nutrition 2000, 130:139-145.
24. Carbo N, Ribas VV, Busquets S, Alvarez B, Lopez-Soriano FJ, Argiles JM: Short-term effects of leptin on skeletal muscle protein metabolism in the rat. J Nutr Biochem 2000, I I:431-435.

25. Anthony JC, Lang CH, Crozier SJ, Anthony TG, MacLean DA, Kimbal $S R$, Jefferson LS: Contribution of insulin to the translational control of protein synthesis in skeletal muscle by leucine. Am J Physiol 2002, 282:EI092-EIIOI.

26. el Razi, Curi R, Carpinelli AR: Utilization of rat and human sera to carry out incubation and perfusion of pancreatic islets. Pharmacol Toxicol Meth 1992, 28:18I-I84.

27. Fernandes LC, Machado UF, Nogueira CR, Carpinelli AR, Curi R: Insulin secretion in Walker 256 tumor cachexia. Am J Physiol 1990, 258:EI033-EI036.

28. Rhoads RE: Regulation of eukaryotic protein synthesis by initiation factors. J Bio Chem 1993, 268:3017-3020.

29. Merrick WC: Mechanism and regulation of eukaryotic protein synthesis. Microbiol Rev 1992, 56:29I-3I5.

30. Prévôt D, Darlix JC, Ohlmann : Conducting the initiation of protein synthesis: the role of elFs. Biol Cell 2003, 95: I4I-156.

3I. Anthony JC, Anthony TG, Kimball SR, Jefferson LS: Signalling pathways involved in translational control of protein synthesis in skeletal muscle by leucine. J Nutrition 200I, I 3 I:856S-860S

32. Ventrucci G, Mello MAR, Gomes-Marcondes MCC: Effects of leucine supplemented diet on intestinal absorption in tumor bearing pregnant rats. BMC Cancer 2002, 2: I-8.

33. Tisdale JM: Tumor-host interactions. I Cel Biochem 2004 93:87I-877

34. Smith HJ, Greenberg NA, Tisdale JM: Effect of eicosapentaenoic acid, protein and amino acids on protein synthesis and deg. radation in skeletal muscle of cachectic mice. Br J Cancer 2004, 91:408-4I2.

35. Yoshizawa F, Kimball SR, Vary TC, Jefferson LS: Effect of dietary protein on translation initiation in rat skeletal muscle and liver. Am J Physiol Endocrinol Metab 1998, 275:E8I4-E820.

36. Duggleby SL, Jackson AA: Protein, amino acid and nitrogen metabolism during pregnancy: how might the mother meet the needs of her fetus? Cur Opin Clin Nutr Metabol Care 2002, 5:503-509.

37. Kalhan SC: Protein metabolism In pregnancy. Am J Clin Nutr 2000, 7 I(suppl): I 249S-55S.

38. Bergen WG: Translational control: a mechanistic perspective. I Nutrition 200I, I 3 I:2976S-2977S

39. Yoshizawa F: Regulation of protein synthesis by branchedchain amino acids in vivo. Biochem Bioph Res Com 2004, 313:417-422.

40. Pain VM: Initiation of protein synthesis in eukaryotic cells. Eur | Biochem 1996, 236:747-77|.

4l. Sonenberg N, Dever TE: Eukaryotic translation initiation factors and regulators. Cur Opin Struc Biol 2003, 13:56-63.

42. Raught B, Gingras AG, Gygi SP, Imataka H, Morino S, Gradi A, Ruedi $A$, Sonenberg N: Serum-stimulated, rapamycin-sensitive phosphorylation sites in the eukaryotic translation initiation factor 4GI. EMBO / 2000, 19:434-444.

43. Jurasinski C, Gray K, Vary TC: Modulation of skeletal muscle protein synthesis by amino acids and insulin during sepsis. Metabolism 1995, 44: I | 30- I I38.

44. Vary TC, Jefferson LS, Kimball SR: Insulin fails to stimulate muscle protein synthesis in sepsis despite unimpaired signalling to 4E-BPI and S6KI. Am J Physiol 200I, 28I:EI045-EI 053.

45. Anthony JC, Yoshizawa F, Anthony TG, Vary TC, Jefferson LS, Kimball SR: Leucine stimulates translation initiation in skeletal muscle of postabsorptive rats via a rapamycin-sensitive pathway. J Nutrition 2000, 130:2413-2419.

46. Yoshizawa F, Sekizawa H, Hirayama S, Hatakeyama A, Nagasawa T, Sugahara K: Time course of leucine-induced 4E-BPI and S6K I phosphorylation in the liver and skeletal muscle of rats. J Nutr Sci Vitaminol 200I, 47(4):3II-5.

47. Shah OJ, Anthony JC, Kimball SR, Jefferson LS: 4E-BPI and S6K I: translational integration sites for nutritional and hormonal information in muscle. Am J Physiol: Endocrinol Metab 2000, 279:E7I5-E729.

48. Dennis PB, Fumagalli S, Thomas G: Target of rapamycin (TOR): balancing the opposing forces of protein synthesis and degradation. Cur Opin Gen Dev 1999, 9:49-54.

49. Greiwe JS, Kwon G, McDaniel ML, Semenkovich CF: Leucine and insulin activate p70S6 kinase through different pathways in 
human skeletal muscle. Am J Physiol: Endocrinol Metab 200I, 28I:E466-E47I.

50. Hara K, Yonezawa K, Weng QP, Kozlowski MT, Belham C, Avruch J: Amino acid sufficiency and $m$ TOR regulate p70 S6 kinase and elF-4EBP I through a common effector mechanism. J Biol Chem 1998, 273:1484-1494.

5I. Shigemitsu K, Tsujishita Y, Miyake H, Hidayat S, Tanaka N, Hara K, Yonezawa K: Structural requirement of leucine for activation of p70S6 kinase. FEBS Lett 1999, 447:303-306.

52. Kimball SR, Jefferson LS: Molecular mechanisms through which amino acids mediate signaling through the mammalian target of rapamycin. Cur Opin Clin Nutr Met Care 2004, 7:39-44.

53. Yoshizawa F, Hirayama S, Sekizawa H, Nagasawa T, Sugahara K: Oral administration of leucine stimulates phosphorylation of $4 \mathrm{E}$ bPI and S6K I in skeletal muscle but not in liver of diabetic rats. J Nutr Sci Vitaminol 2002, 48(I):59-64.

54. Harris RA, Joshi M, Jeoung NH: Mechanisms responsible for regulation of branched-chain amino acid catabolism. Biochem Bioph Res Com 2004, 3 I 3:391-396.

55. Tokunaga $C$, Yoshino $K$, Yonezawa $K$ : $\mathbf{m}$ TOR integrates amino acid and energy sensing pathways. Biochem Bioph Res Com 2004, 31 3:443-446.

56. Desai BN, Myers BR, Schreiber SL: FKBPI2-rapamicyn associated protein associates with mitochondria and senses osmotic stress via mitochondrial dysfunction. Proc Nat Acad Sci USA 2002, 99:4319-4324.

57. Xu G, Kwon G, Cruz WS, Marshall CA, McDaniel ML: Metabolic regulation by leucine of translation initiation through the mTOR-signaling pathway by pancreatic beta-cells. Diabetes 200I, 50:353-360.

58. Curi R, Homem-de-Bittencourt PI Jr, Costa-Rosa LF, Fernandes LC, el-Razi S, Seelaender MC, Carpinelli AR: Insulin and prostaglandins as signals between tumor and the host immune system. Braz J Med Biol Res 1995, 28:773-779.

59. Argiles JM, Alvarez B, Lopez-Soriano FB: The metabolic basis of cancer cachexia. Med Res Rev 1997, 17:477-498.

60. Prod'homme M, Rieu I, Balage M, Dardevet D, Grizard J: Insulin and amino acids both strongly participate to the regulation of protein metabolism. Cur Opin Clin Nutr Met Care 2004, 7:7I-77.

61. Kimball SR, Shantz LM, Horetsky RL, Jefferson LS: Leucine regulates translation of specific mRNAs in $\mathrm{L} 6$ myoblasts through mTOR mediated changes in availability of elF4E and phosphorylation of ribosomal protein 56. J Biol Chem 1999, 274: II647-II652.

62. liboshi Y, Papst PJ, Kawasome H, Hosoi H, Abraham RT, Houghton $\mathrm{PJ}$, Terada N: Amino acid-dependent control of p70(s6k). Involvement of tRNA aminoacylation in the regulation. J Biol Chem 1999, 274: 1092-1099.

63. Bolster DR, Vary TC, Kimball SR, Jefferson LS: Leucine regulates translation initiation in rat skeletal muscle via enhanced elF4G phosphorylation. J Nutrition 2004, 134: 1704- 1710.

64. Patti M, Brambilla E, Luzi L, Landaker EJ, Kahn CR: Bidirectional modulation of insulin action by amino acids. J Clin Invest 1998, 101:1519-1529.

\section{Pre-publication history}

The pre-publication history for this paper can be accessed here:

http://www.biomedcentral.com/1471-2407/7/42/prepub
Publish with BioMed Central and every scientist can read your work free of charge

"BioMed Central will be the most significant development for disseminating the results of biomedical research in our lifetime. "

Sir Paul Nurse, Cancer Research UK

Your research papers will be:

- available free of charge to the entire biomedical community

- peer reviewed and published immediately upon acceptance

- cited in PubMed and archived on PubMed Central

- yours - you keep the copyright
BioMedcentral 